\title{
ŘÍZENÍ ŠKOLY A VYTVÁŘENÍ UČÍCÍ SE ORGANIZACE
}

\author{
LENKA SLAVÍKOVÁ †
}

\begin{abstract}
Anotace: Článek se zabývá stručnou charakteristikou změn ve společnosti, které podmiňují proměnu školy, zmiňuje základní principy tvorby učící se organizace z hlediska vedení školy. Pozornost je věnována kompetencím rídících pracovníků a jejich rolím při řizení změny a vytváreni týmů, což jsou klíčové dovednosti a schopnosti pro rízení školy jako učící se organizace.
\end{abstract}

Klíčová slova: znalostní společnost, učící se organizace, kompetence, leader, manažer, rízení změny, vedení týmů

Abstract: Main topic of this article is focused on the leading and managing schools as a learning organizations. The first part is orientated on the brief characteristic of the learning organization in the relationship with the requirements of the employment market on the school leaders competences. Second part reviews various attitudes to the creation of the schools as a learning organization from leader and manager, team management and change management point of view.

Key words: knowledge society, learning organizations, change management, team leading and team management, leadership

\section{Úvod}

Od útlého věku jsme vedeni $\mathrm{k}$ tomu, abychom problémy rozebírali na části. To nám umožňuje zvládat složitější témata a úkoly, ale platíme za to mimořádně vel-

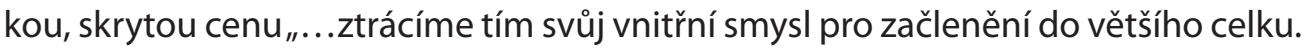
Ve chvíli, kdy se snažíme vidět celkový obraz, se pokoušíme v mysli složit a propojovat všechny kousky a uspořádat je. Vzhledem k tomu, že svět je stále propojenější, vzájemně závislejší, musíme se naučit vnímat nikoli jeho izolovanost, ale jeho komplexnost, naše práce se musí stát »učeníplnějšíi.... Můžeme se snažit vytvořit »učící se organizaci«, v níž lidé nepřetržitě rozšiřují své schopnosti dosahovat výsledků, po nichž skutečně touží, kde se věnuje péče novým a objevným způsobům myšlení a kde se lidé neustále učí, jak se společně učit, protože organizace, které v budoucnosti skutečně vyniknou, budou ty, jež přijdou na to, jak ke svému prospěchu využít soustředěného zaujetí lidí a jejich schopnosti se učit... Učící se organizace jsou možné proto, že jsme v podstatě všichni stále učícími se žáky..." (Senge, 2007, s. 21). 


\section{Proměna společnosti - proměna školy}

Změny ve společnosti žádají proměnu školy, úspěšná proměna školy je do značné míry podmíněna proměnou managementu.

Správným předpokladem dnešní společnosti je, že to, čemu se jedinci naučí do jednadvaceti let, bude do pěti až deseti let překonáno a bude muset být nahrazeno či doplněno novým učením, novými znalostmi, novou kvalifikací. To, čemu se žáci a studenti naučí ve škole, se stává odrazovým můstkem, základem, na němž si budují svou další životní dráhu. Nejstabilnějším prvkem a centrem společnosti se musí stát školy, poněvadž kvalita vzdělávání dnes vytváŕí podmínky pro úspěšné zapojení se do života a ti, kdo nezískali vzdělání, at na začátku své profesní dráhy či v jejím průběhu, se velmi pravděpodobně dostanou do sociální exkluze.

Každý dynamický rozvoj vědy má však kromě pozitiv i negativní důsledky, zejména $v$ případě, když ruku v ruce s rozvojem vědy nedochází $k$ rozvoji a vytváření mravních, etických a lidských hodnot. Pokud chceme dosáhnout proměny společnosti, je nutno docílit především proměny školy. Její úloha dnes, více než v minulosti, přesahuje vzdělanostní rámec a zasahuje oblast etickou a lidskou. Pokud chce být škola úspěšná, musí vytvářet a budovat svou vlastní identitu a osobitost, hledat nové myšlenky, snažit se je realizovat a formulovat ve vizích a strategických cílech, musí anticipovat změny v oblasti společenské, ekonomické a legislativní, vnímat souvislosti technologické, politické a kulturní. Tyto úkoly nelze zvládnout bez týmové spolupráce, delegování pravomocí, komunikace a schopnosti rozhodovat, bez profesionálního vedení lidí, poněvadž rízení dnes neznamená dominanci, ale umění presvědčit zaměstnance, aby společně pracovali na dosažení strategického cíle.

V průmyslové společnosti bylo nutno, aby na změny reagovaly profesionálně především ziskové organizace, které se chtěly prosadit a být úspěšnými. Dnes platí stejné zákonitosti také pro organizace neziskové, tedy i školy, které v tomto prostředí změn, charakterizované vlivy informační společnosti, vědy, techniky a internacionalizací, existují a musí na ně být připraveny, musí na ně nejen reagovat, ale dokonce je predvídat.

Na změnu v pojetí vzdělávání a chápání významu celoživotního učení reagovala samozřejmě i Evropská unie, která formulovala 13 dílčích cílů pro zvýšení efektivity vzdělávání na lisabonském summitu. Jedním z nich je - Rozvíjet klíčové kompetence ve společnosti založené na znalostech; dalším bodem, významným z pohledu škol a podpory procesu učení se, jsou stanovené akční oblasti konkurenceschopnosti Evropy: rozvoj celkové kompetence jednotlivců, príprava jednotlivce i společnosti na celoživotní učení' . (Lisabonská smlouva 2007)

Na tento materiál navazuje v roce 2007 vládou schválená Strategie celoživotního učení ČR, která se stává hlavním principem vzdělávací politiky u nás. Vychází z pojetí Evropské komise, která rozpracovává koncept celoživotního učení a zdůrazňuje přístup zaměřující se na širokou poznatkovou základnu a rozvíjení schopností

1 kráceno L. Slavíková 
jednotlivců účastnit se ekonomického života, tzn. zaměstnatelnosti na trhu práce. Současné pojetí celoživotního učení spojuje ekonomickou, sociální, environmentální a kulturní dimenzi a směřuje $k$ učící se společnosti (Strategie celoživotního učení ČR, 2008).

SpInění výše uvedených požadavků vyžaduje proměnu školy, jedním z možných modelů může být řízení školy jako učící se organizace. Tento model však vyžaduje od všech účastníků výchovně vzdělávacího procesu nové kompetence - od žáků, učitelů, a především řídících pracovníků. Jedná se totiž o vzájemně propojený systém. Pokud má získat nové kompetence žák, musí být veden kompetentním učitelem, ten by měl být veden kompetentním rídícím pracovníkem.

\section{2. Škola budoucnosti a charakteristika učící se organizace}

V dokumentech vzdělávací politiky najdeme koncepty školy budoucnosti v návaznosti na vize vývoje společnosti. Nejčastěji jsou zmiňovány vize společnosti založené na znalostech (společnost vědění), společnosti založené na informacích, společnost založená na procesuálním učení se (společnost učící se). I když se jednotlivé přístupy částečně liší - společnost založená na znalostech akcentuje spíše ekonomické hledisko, učící se společnost zahrnuje i aspekt sociální a eticko-morální, najdeme dva hlavní sjednocující prvky - v učící se i znalostní společnosti si občané, organizace, firmy a podniky váží vzdělávání, podporují je, považují účast na něm za samozřejmost, úkolem veřejných a státních institucí je podporovat vzdělávání a učení, zejména učení celoživotní.

Druhým významným momentem je práce s informacemi - znalostní i učící se organizace charakterizuje jiný prístup k získávání a zejména využívání informací, znalostí, vědomostí a dovedností než doposud, nejde pouze o to vědět že, ale vědět jak, vědět proč a vědět kdy. Jinými slovy nejedná se o získání co největšího souhrnu informací a nejlepších postupů, ale jedná se především o vytvoření pracovních komunit, týmů, které udržují a obnovují prostřednictvím učení znalosti o určitém tématu a sdílejí to, co vědí. Nejedná se o sumu informací, které jsou známy k určitému časovému momentu, ale o stále se vyvíjející tok znalostí a informací udržovaný v aktuální podobě lidmi, kteří jej pravidelně sdílejí, používají a dále posunují. Sdílením informací dochází k synergickému efektu.

Myšlenka učící se organizace byla rozpracována a již v roce 1990 v USA prezentována jako nový koncept managementu, který významně zasáhl do proměny rízení organizací. Původně byly principy učící se organizace využívány zejména v ziskovém sektoru, nyní jsou velmi úspěšně aplikovány v celosvětovém měřítku při řízení neziskových organizací - zejména škol a školských zařízení. Důvodů je několik (napr.):

a. propojenost ekonomik zasahuje jak ziskové, tak neziskové organizace - vývoj poznatků v jednotlivých oborech, vstup informačních technologií do každodenního života občanů, nový systém přenosu dat a získávání poznatků, vstup internetu do života profesního, soukromého i do výchovně vzdělávacího procesu (což mj. znamená, že škola přestává být hlavním zdrojem 
informací nejen pro žáky, ale i učitele)

b. vzdělání se stává ekonomickou kategorií - „ziskem“

c. základní principy řízení ziskových i neziskových organizací jsou ve znalostní společnosti stejné (strategické plánování, motivování lidí, týmové rízení, reakce na konkurenční prostředí, sdílení informací, předvídání změn...)

d. mění se požadavky na kompetence rídících pracovníků jak v ziskových, tak v neziskových organizacích; díky premisi celoživotního vzdělávání se zvyšuje úroveň vzdělání podřízených, kteří tak sami získávají nové kompetence a vyžadují od svých nadřízených odklon od direktivního stylu řízení, vysvětlení, pochopení úkolů, které mají dělat, svobodu rozhodování a spolupodílení se na strategii rozvoje organizace - firmy i školy.

Učící se organizace je tedy taková organizace, kde se zaměstnanci dobrovolně snaží neustále rozšiřovat své vědomosti a dovednosti, potřebné pro budoucí úspěšnost organizace. Termín učící se organizace vyjadřuje či charakterizuje atmosféru, klima, kulturu, v nichž je vedením školy podporováno experimentování, výměna zkušeností, sdílení informací nejen mezi učiteli, ale i mezi učiteli a žáky.

Hovoříme-li o škole jako o učící se organizaci, musí procesuálně vykazovat několik základních znaků. Používáme-li slovo procesuálně, máme tím na mysli, že stát se učící se organizací není jev trvalý, ale jedná se o nikdy nekončící proces. Znaky učící se organizace jako jeden z prvních uvádí Peter M. Senge (2007, upraveno pro školu L. Slavíková):

\section{Mistrovství v oboru:}

Učitelé jsou nejen mistry ve svém oboru, ale jsou nadále otevření vưči novinkám, zajímají se o vývoj ve své odbornosti, o nové technologie, zaznamenávají změny a uplatňují je př́ výchovně vzdělávacím procesu. Snažit se "být mistrem“ je nikdy nekončící proces učení se a přemýšlení - ne titul, ale způsob života a postoje ke světu.

\section{Mentální modely:}

Učitelé umí sami vyhodnotit, kdy pracují rutinně podle zaběhaných "modelü“, kdy používají stejné metody práce, stejné postupy při výchovně-vzdělávacím procesu a současně umí vyhodnotit, kdy je nutno dosavadní model změnit. Mentální modely souvisí s profesionálně realizovanou zpětnou vazbou a vnitřním sebehodnocením. Jsou schopni vyhodnotit, které postupy jsou méně funkční nebo zcela nefunkční a snaží se je změnit. Nelze toto téma zpracovat jinak? Jak zapojit žáky do procesu učení se o problematice.

\section{Sdílení vizí:}

Škola má stanovenu vizi, na jejiž tvorbě se podíleli pokud možno všichni pracovníci, s vizí jsou nejen srozuměni, ale podporujíji a sdílí. Škola, jako každá organizace, je soubor individualit, každý z účastníkủ či aktérů výchovně-vzdělávacího procesu má své vlastní představy o své roli ve škole, míre seberealizace, každý člověk má jiná přání. Sdílené vize fungují proto jako hlavní, řídící společné principy, s nimiž jsou lidé ztotožněni a vlastní cíle si stanovují v rámci této obecně sdílené vize.

4. Týmové učení. Ve škole je podporována týmová práce, výměna zkušeností. Učitelé (i s žáky) jednají jako tým a ne jako skupina jednotlivců, pracují na zadaných 
úkolech a plní prostřednictvím společného cíle sdílenou vizi. Týmové učení předpokládá důvěru, otevřenost v komunikaci (slyšet, co druzí říkají) a ochotu znalosti a informace sdílet. Základem učících se organizací nejsou špičkoví jednotlivci, ale učící se týmy - ty jsou jednotkami organizace.

5. Systémové myšlení. Je nejdůležitější charakteristikou ze všech. Škola neexistuje ve vzduchoprázdnu, její hranice nekončí za vstupními dveřmi, ale je částí širších vazeb, spoluvytvárí jejich dynamiku. Je třeba ji proto vnímat jako součást vnějšího prostředí, kde existuje řada viditelných, ale i skrytých faktorů, které ovlivňují na základě principu prríčiny a následku procesy vnitřního života školy. Zejména schopnost managementu školy vnímat jevy, problémy systémově, nikoli jako souhrn náhodně se kumulujících jevů, je podmínkou úspěšnosti školy v dnešním turbulentním prostředí, protože proměna školy zasahuje nejen kurikulární oblast - obsah vzdělávání a vyučování, volbu nových metod a forem práce, ale spočívá především v nutnosti změnit myšlení a postoje lidí - rodičů, zřizovatelů škol, žáků, učitelů.

Na základě výše uvedeného Ize říci, že učící se organizace představuje určitou kvalitu organizace, která vyniká právě svou adaptabilitou na rychlé změny v turbulentním prostředí naší doby. Integrovanou součástí podstaty takovéto organizace je učení se, které jí pomáhá za daných dynamických podmínek získávat stabilitu či dokonce konkurenční výhodu (pokud je její učení se a adaptabilita, reakce, větší než tempo změn - podle rovnice Reg Revanse: U>Z (Tichá, 1999).

Sumarizujeme-li výše zmíněné charakteristiky učící se organizace, je možno shrnout dva hlavní směry v kultuře, klimatu a "spiritu“ školy, která by se chtěla stát učící se organizací a kterých by si měl být ředitel vědom:

a. řídit školu tak, aby byla adaptibilní a pružně reagovala na změny prostředí; ředitel musí klást důraz na její proaktivní chování a ne pouze reaktivní - musí naučit kolegy změny předvídat, nikoli na ně pouze zpětně reagovat.

b. škola musí být vedena a řízena tak, aby učitelé, žáci, pracovní týmy, byli schopni opouštět zavedené, navyklé a důvěrně známé, at již jde o služby, pracovní postupy, mezilidské a sociální vztahy. „Každá organizace musí učinit nedílnou součástí vlastní organizační kultury také řízení změn“ (Drucker, 2002).

Koncept školy jako učíci se organizace rozpracovává jako jeden z prvních u nás J. Kotásek (2004, s. 441-484), když nastiňuje možné scénáře vývoje školy na základě proměny požadavků společnosti. Rovněž práce Vaštatkové, Prášilové (2007, s. 5-11), Pola (2007) ukazují, že aplikace principů učící se organizace je pro školy nejen využitelná, ale téměř zásadní, aby byly schopny svou proměnou reagovat na změny, které zasahují podstatu celého systému školy od stylu ř́zení, způsob výuky kurikula, po práci s žáky a učiteli. Př́spěvek Vaštatkové, Prášilové (2007, s. 5-11) však současně dokumentuje, jak obava škol (jejich pracovníků) z přiznání případných nedostatků a chyb $v$ práci může $v$ českém prostředí překážet $v$ přijetí tohoto konceptu.

\subsection{Učící se organizace a kompetence ředitele školy}


Základním rysem učící se organizace z hlediska řízení je delegování pravomocí a spoluúčast členů organizace na rozhodování, zdokonalování a učení se - toto již není pouze záležitostí vrcholového managementu, ale všech členů organizace učitelů a ve svém důsledku i žáků. Motto - vést, nikoli pouze řídit a vykonávat dané úkoly platí nejen pro ředitele školy ve vztahu k učitelům, ale i pro učitele ve vztahu k žákům. Kompetence leadera jsou vyžadovány jak od ředitele školy, tak i od učitelů, aby se mohli žáci a studenti - absolventi „školy současnosti“ úspěšně uplatnit na trhu práce „budoucnosti". Ten od nich bude vyžadovat rovněž kompetence leaderů - ochotu učit se, práci v týmu, rychlou reakci na změnu, adaptabilitu, schopnost brát na sebe zodpovědnost za svá rozhodnutí ....(viz úvodní citát).

Řízení školy jako učící se organizace proto představuje pro vedení školy vyšší nároky z hlediska uplatňovaných stylů rízení a jeho kompetencí. Nejedná se o kompetence $v$ oblasti právní či ekonomické, ty jsou dány ze zákona, ale o oblast vůdcovství - motivování, personální rízení, sdílení vizí, strategického plánování apod.

V obecné rovině se pojem kompetence vysvětluje jako schopnost, způsobilost, pravomoc či moc, u řídících pracovníků je nejčastěji používán termín manažerské kompetence, který zahrnuje dva př́stupy:

1. Kompetence od jiného - jedná se o soubor rozhodovacích pravomocí, které vyplývají z pozice funkce ředitele školy, jsou dány zejména ze strany zřizovatele (od formální autority). Z nich pak vyplývá odpovědnost za důsledky rozhodovacích procesů (můžeme spojit i s termíny - moc, vliv, poziční autorita).

2. Kompetence od sebe - jedná se o obecné schopnosti adekvátně zhodnotit situaci a dokázat jí přizpůsobit své jednání, prípadně umět na situaci reagovat zásahem do systému, který se v důsledku tohoto proaktivního jednání žádoucím způsobem promění (kompetence od sebe) - tedy schopnost, způsobilost (skill, qualifiction), jedná se o způsobilost, skutečnou profesionalitu. Někdy se používá termín pracovní způsobilost, profesní kompetence. Jsou spjaty s oblastí emoční inteligence.

Na kompetence řídícího pracovníka se můžeme podívat i prostřednictvím rolí, které vykonává při řízení školy:

1. Role vůdce, leadera - nejčastěji zařazovaná do tzv. měkkých kompetencí, nebo kompetencí „od sebe“. Jedná se např. o motivování lidí ke spoluvytváření strategického rámce rozvoje školy a sdílených vizí, personálního řízení. Z této role vyplývají kompetence umět formulovat myšlenky, schopnost analýzy a vyhodnocování informací, emoční inteligence, rozeznání silných a slabých stránek podřizených, komunikace - naslouchání apod. Z pohledu řízení učíci se organizace kompetence nezbytná, základní.

2. Role manažera - hraniční, zařazována částečně do kompetencí měkkých "od sebe", ale i do kompetencí daných „od jiného“. Jedná se o to, aby strategické cíle a vize byly dosaženy. Tuto roli Ize vnímat jako nejkomplikovanější, poněvadž se jedná o kompetence zahrnující i oblast autority, moci, oblast kontroly, organizování, ale i vyhodnocování myšlenek, rozhodování, schopnost principiálního vyjednávání, akceptace myšlenek, řizení lidských 
zdrojů, vyhodnocování zpětné vazby. Pro učící se organizaci kompetence doplňující a nutná.

3. Role vykonavatele - zařazovaná do kompetencí "daných od jiného"(od formální autority). Vždy je spjata s typem organizační struktury školy a z ní vyplývající rozhodovací pravomoci. $V$ učící se organizaci by mohla a měla být vykonávána jinou osobou než ředitelem školy, bohužel tomu často tak není.

V ziskových organizacích, které fungují jako učící se organizace, představují tři výše zmíněné role většinou tři jednotlivé úrovně managementu, jiné skupiny lidí (či jedince). Maximálně dochází k propojení funkce vůdce a manažera, nikdy však i vykonavatele. Při stávajícím systému hodnocení a stanovených kritérií ze strany zřizovatelů a ČŠl jsou ředitelé, kteří vstoupí do procesu vytváření učící se organizace, nuceni aktivně plnit všechny tři role.

Nejen teorie učící se organizace, ale především školská praxe jednoznačně ukazují, že pro kvalitu školy je podstatná kvalita řídících pracovníků v oblasti personálního ř́zení, motivování, výběru pracovníků, delegování úkolů, vytváření koncepcí - tedy role leadera a manažera, z pohledu zřizovatelů však bývá kvalita managementu a školy spojována především s hodnocením kvality vykonavatele: „účelem hodnocení je zjištění, zda ředitel plní právní povinnosti vyplývající z vykonávané funkce, či je závažně neporušuje... Při hodnocení je přihlíženo ke zprávám o činnosti organizace, pokud jsou zpracovány, ke koncepci rozvoje organizace zpracované ředitelem a ke koncepční práci ředitele." (kritéria hodnocení odboru školství krajského úřadu v ČR, kráceno L. Slavíková).

Tab. 1

\begin{tabular}{|l|l|}
\hline Leader & Manažer \\
\hline zavádí změny a vyvijí nové postupy & kontinuálně vykonává správní činnosti \\
\hline vybízí k zachování statutu quo & přijímá status quo \\
\hline $\begin{array}{l}\text { zaměřuje svou pozornost na lidský } \\
\text { faktor }\end{array}$ & $\begin{array}{l}\text { zaměřuje svou pozornost na } \\
\text { fungování systému }\end{array}$ \\
\hline řeší věci s dlouhodobou perspektivou & řeší aktuální problémy \\
\hline nezabývá se detaily & bere v úvahu detaily, jednotlivosti \\
\hline vytváří pozitivní atmosféru & spoléhá se na kontrolu \\
\hline ptá se co a proč & ptá se jak a kdy \\
\hline někdy mění pravidla & vždy dodržuje pravidla \\
\hline ukazuje směr, vizi & plánuje a zpracovává rozpočet \\
\hline sjednocuje a inspiruje zaměstnance & pojmenovává a řeší problémy \\
\hline motivuje zaměstnance & organizuje a personálně zajištuje \\
\hline
\end{tabular}

Zdroj: Slavíková ( 2007)

Problematice vedení a rrízení se v posledních pěti letech věnují nejen ziskové, ale i neziskové organizace, např. Schratz (2007) používá pro vymezení leaderů a mana- 
žerů dvojjediný model vycházející z jing a jang struktury, kde v podstatě naznačuje nutnost zvládnout obě role a funkce, pokud má být rídící pracovník úspěšný. Pol (2007, s. 31) rovněž uvádí, že „otázka leader nebo manažer je spíše řečnická, poněvadž většina autorů upozorňuje, že oddělovat vedení a řizení od sebe nebývá bez problémů".

Klíčem k úspěchu ředitele školy se jeví spíše schopnost neboli „kompetence od sebe" odlišit, kdy a v jakých situacích má využívat spíše své portfolio leadera, kdy manažera. Řízení školy jako učíi se organizace vyžaduje především vysokou úroveň kompetencí leadera.

Zajímavá zjištění na otázku stanovení kompetencí u řídících pracovníků přinesl výzkum Centra školského managementu PedF UK, které bylo v období 2006 - 2008 řešitelem národního projektu ESF Úspěšný ředitel: Profesionalizační příprava Studium pro vedoucí pedagogické pracovníky. Cílovou skupinou výzkumu bylo tři sta vedoucích pracovníků úplných škol poskytujících základní vzdělání a vedoucí pracovníci mimopražských středních škol, případně mimopražských vyšších odborných škol (z toho 152 mužů a 148 žen) ze všech krajů republiky, s výjimkou Prahy. V rámci evaluace projektu probíhala řada výzkumů, jedno z nejrozsáhlejších šetření bylo zaměřeno na analýzu kompetencí rídících pracovníků ve školství, a to $v$ několika rovinách. První rovinou bylo vyjádření ideálního stavu, kterého by měli řídící pracovníci v jednotlivých kompetencích dosáhnout, další bylo subjektivní posouzení vlastních kompetencí vzhledem ke své osobě.

Jednotlivé kompetence byly pojmenovány autory dotazníku a respondenti vyplňovali u každé z nich stanovené hodnoty. V následujícím grafu jsou uvedeny dvě vážící se k problematice řízení učící se organizace:

1. Ideální hodnota kompetencí, potřebných pro výkon funkce řídícího pracovníka

2. Odhad vlastní úrovně kompetencí

Možnosti byly stanoveny na škále 0 - 6, (0 - nedostačující, 6 vynikající); kompetence vycházely ze tři výše uvedených rolí a byly členěny do následujících dílčích oblastí:

1. Kompetence kognitivní, teoretické znalosti a kontextové vědomosti komplex znalostí jednotlivých oblastí (právo, ekonomika, teoretická východiska managementu apod.), jejich zapojení do práce ředitele školy a vzájemné souvislosti. Tradičně jsou tyto kompetence řediteli škol hodnoceny velice vysoko, koresponduje $s$ tím chápání ředitele jako člověka odpovědného za právní a ekonomické záležitosti škol. Stejným způsobem chápe tuto složku řídící práce jako nejdůležitější státní správa reprezentovaná v tomto výzkumu pracovníky krajských úradů a České školní inspekce.

2. Schopnost hodnotit a kontrolovat. Jde o jednu ze základních manažerských kompetencí, nebot bez systémů zpětnovazebních údajů nelze rídit žádnou organizaci.

3. Personální kompetence. Vedení lidí, kooperace, komunikace s lidmi na nejrůznějších úrovních - zaměstnanci, rodiče, žáci, pracovníci zastupitelstev, 
státní správy a další osoby vstupující do života školy..

\section{4. Řízení sebe sama.}

\section{Schopnost řešit problémy..}

6. Sebedůvěra. Bez této kompetence není možno aspirovat na rídící funkci $v$ kterémkoli oboru lidské činnosti.

\section{Koncepční práce.}

8. Schopnost učit se.

\section{Zvládání změn a jejich řízení.}

Grafické vyjádření dosažených výsledků zobrazuje jednak vysokou aspiraci řídících pracovníků ve školství na všechny kompetenční oblasti - vykonavatele, manažera i vůdce. V položce »ideální hodnota kompetencí« se žádná hodnota nedostala pod položku 5.

Odhad vlastních kompetencí již dává plastičtější obraz - ředitelé si byli jistější v položkách, spadajících do role vykonavatele - kompetence kognitivní a schopnost hodnotit a kontrolovat; středových hodnot dosáhly kompetence manažerské; nejvyšší rozdíly je možno zaznamenat právě u kompetencí, spadajících do portfolia leadera - zvládání změn a jejich řízení, sebedůvěra, řízení sebe sama. Jedním z možných důvodů je to, že ředitelé jsou hodnoceni zřizovateli převážně jako vykonavatelé a manažeři, minimálně jako leadeři, proto i odhad úrovně vlastních kompetencí je takto uváděn.

\section{Tab. 2}

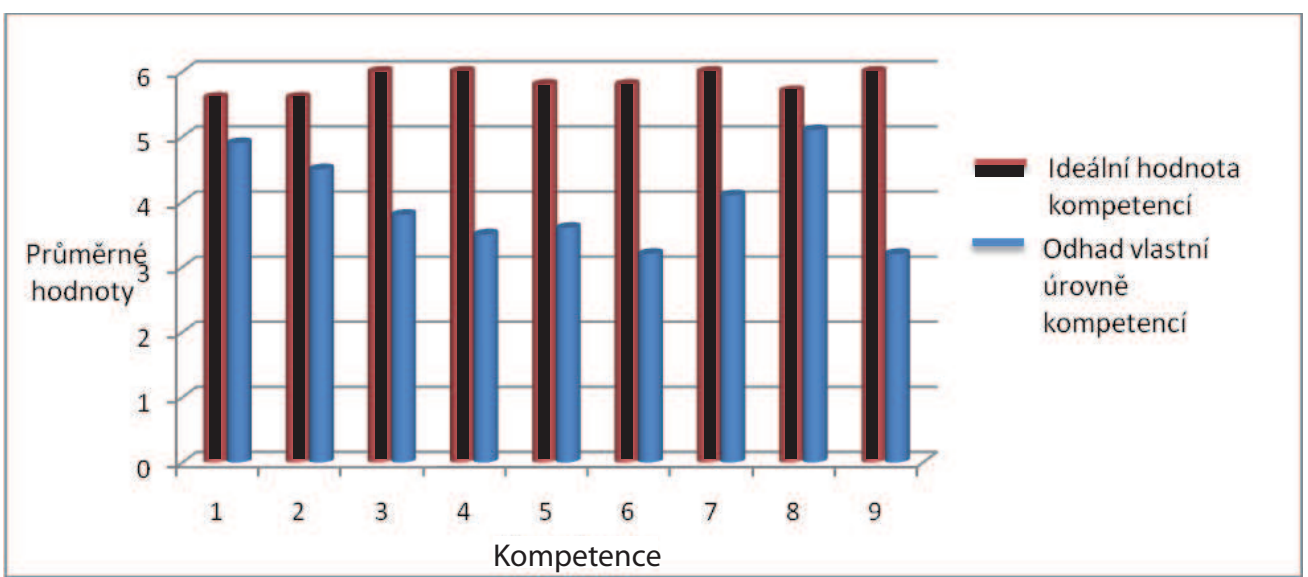

Zdroj: (Slavíková, 2008)

Dílčí část výzkumného šetření rovněž ukázala, že ředitel školy v nových společenských podmínkách musí plnit trojjedinou roli - vůdce, manažera i vykonavatele, poněvadž první dvě jsou oprávněně vnímány jako klíčové nejen učiteli, ale $\mathrm{i}$ samotnými řediteli, poslední role - vykonavatele - je především vyžadována a hodnocena ze strany zřizovatelů a kontrolních orgánů. Jen těžko najdeme ve školství 
komplexnější a složitější roli, než je role ředitele.

\subsection{Profesionální řízení změny a vedení týmů v učící se organizaci}

Pro úspěšné řízení učící se organizace musí být ředitel leaderem a zvládat profesionální rízení změny a vedení týmů. Škola se začne měnit v učící se organizaci, jestliže všichni budou nejen tuto změnu akceptovat, ale prijimou ji za svou a budou se tak moci připravit na další změny, které jim požadavky společnosti přinesou. Této problematice byla věnována řada publikací, odborných prací, ale stále je třeba některé řídící pracovníky přesvědčovat o tom, že úspěch změny nezávisí na modernizaci budovy školy, na vybavení novými počítači. Podstatné je, jak dovede ředitel vyhrát $v$ bitvě $s$ myšlením a vědomím lidí. Řídit učící se organizaci znamená vést aktivní tým spoluhráčů, kteří nejen pozitivně reagují na změnu pravidel hry, ale výměnou zkušeností, vyhodnocením optimálních postupů v minulosti a rizik v budoucnosti vyberou spolu s koučem vhodnou taktiku odpovídající novému hřišti, stanoví si cíl a k němu odpovídající strategii. Pokud začnou prohrávat, nečekají až do konce zápasu, nečekají na povel kouče, ale sami začnou uvažovat o změně společně zvolí jinou strategii, obmění tým, povolají další hráče... Možností je řada - od změny strategie, cíle, po změnu hřiště, hráčů - až výměnu kouče.....

Profesionálně řídit proměnu školy v učící se organizaci znamená pro ředitele použít následující kroky:

Ředitel - leader musí vytvořit vědomí potřebnosti proměny školy, její nutnosti a naléhavosti - jednou z největších chyb je, když se management vrhá do jakýchkoli změn ve škole, aniž přesvědčí předem své spolupracovníky o jejich naléhavosti. Ředitel musí představit změnu jako nutnost, která donutí zaměstnance změnit své dosavadní vzorce chování, ale přinese nové př́ležitosti. Ředitel by měl charakterizovat základní principy učící se organizace, stanovit na základě analýzy kroky, které je potřeba učinit, aby proces mohl být zahájen, a seznámit s ním kolegy. Upozornit na rizika, např.: pokud škola nebude na změny ve společnosti reagovat, stane se postupně nekonkurenceschopnou, což ve svém důsledku má dopad nejen na ředitele, ale na samotné učitele. Druhým krokem je správná komunikace. Vytváření učící se organizace předpokládá - zapojení „,srdce i mozku“ zaměstnanců. Již od počátku musí všichni vědět jaké: a) výhody, b) problémy (oběti) nastanou při tomto procesu. Lidé musí být přesvědčováni o tom, že změna je nejen nezbytná, ale i správná a pro všechny navzájem spravedlivá. Součástí správně vedené komunikace v učící se organizaci je umění vytvořit přesvědčení, že všechno není předem rozhodnuto, že jsou ještě přiležitosti, ve kterých lidé mohou uplatnit své návrhy řešení. Třetím krokem je vytvoření skupiny lidí, kteří využívají své „mistrovství" a budou spolu $s$ vedením školy tvorbu učíci se organizace a další změny prosazovat. Zásadní změny nemůže realizovat ředitel školy sám, ale je třeba, aby kolem sebe soustředil tým spolupracovníků, kteří mají vysokou formální i neformální autoritu. Je vhodné do této "přesvědčovací" skupiny zapojit jak členy vedení s formálními funkcemi, tak nečleny vedení - kolegy zkušené, dále ty, kteří jsou schopni získat informace, mají dobré kontakty a především ty, kteří, at již patří ke zkušenějším či méně zkušeným, 
mají mezi členy sboru neformální autoritu. Čtvrtým krokem je uplatňovat strategické rízení, např. vytvořit jasnou a srozumitelnou vizi, která bude zahrnovat obsah i proces proměny školy. „Bez vize se může proces změny lehce rozmělnit do řady zmatených, vzájemně si odporujících a časově náročných projektů, které se ubírají špatným směrem, nebo nikam nevedou" (Kotter, 2000, s. 15).

$\mathrm{K}$ profesním kompetencím vůdce patří i rozvaha, nadhled nad procesem proměny školy $v$ učící se organizaci, poněvadž jako každá změna, i tato, protože jak již bylo uvedeno, být učící se organizací není jev trvalý, ale stav procesuální, má svůj algoritmus vývoje a nesmí být uspěchána, či vyhlášena za uskutečněnou předčasně pouze při prvních signálech mírného zlepšení. „Předčasná oslava vítězství může zastavit vše, co doposud běželo" (Kotter, 2000, s. 20).

Posledním krokem, nikoli však z hlediska významnosti, je proměna od řizení jednotlivce a skupiny $\mathbf{k}$ vedení týmů. Do tvorby školních vzdělávacích programů se o týmovém řízení ve škole př́liš nehovořilo. Požadavek projektových dnů, průřezových témat, ale i koncepčně zpracovaného vlastního hodnocení školy tuto kompetenci posunul na pomysIné škále k velmi vysoké hodnotě. At již hovoříme o učící se organizaci či pouze o škole, jejíž vedení reaguje na požadavky praxe, dá se předpokládat, že se s požadavkem profesionálního vedení týmů setkáme.

Philip Rosengarten (Tichá, 2008) uvádí vedení týmů, týmovou práci a týmové učení jako pomysIný vrchol pyramidy v tvorbě učící se organizace:

Tab. 3

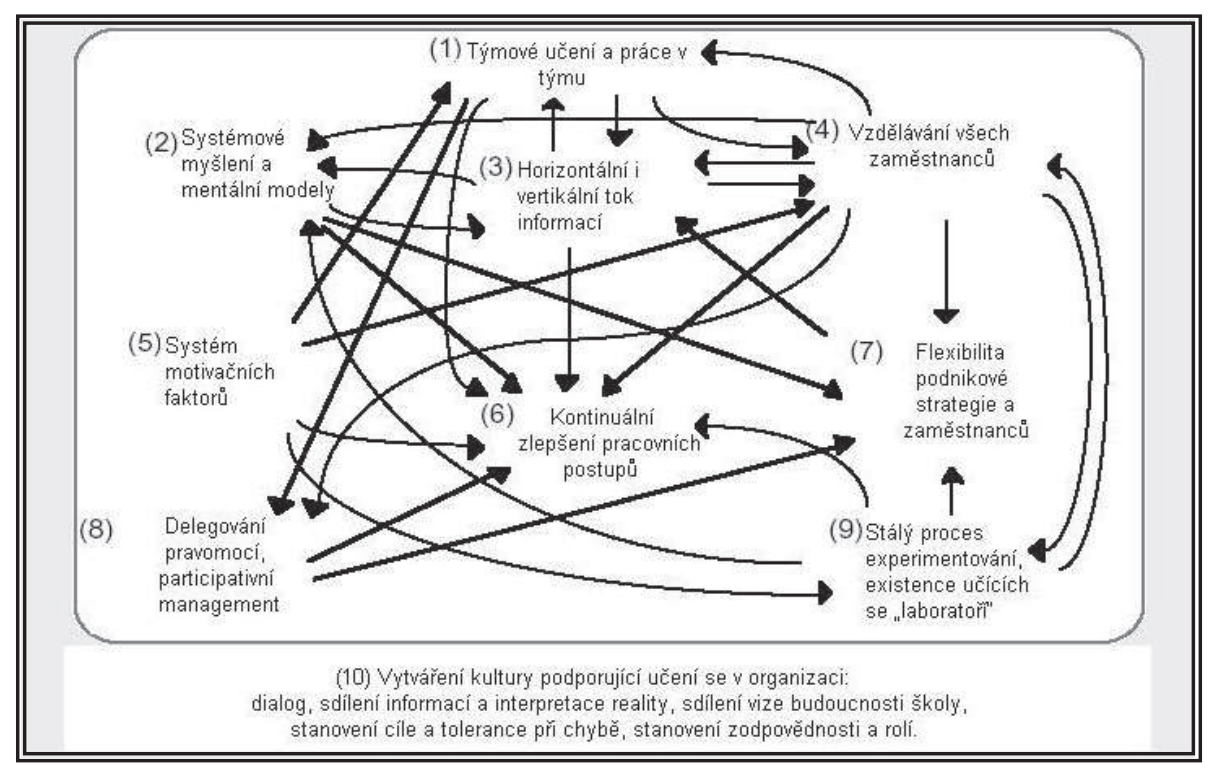

Zdroj: Tichá, 2008

Proč tomu tak je? Poněvadž každá „učící se organizace“ má základní dva zdroje učení - z vlastních zkušeností a ze zkušeností ostatních. Oba dva přístupy se dopl- 
ňují, mají své výhody a nevýhody. Pokud chápeme tým jako skupinu lidí vykonávajících společně nějakou činnost za účelem splnění společného cíle, je zřejmé, že při optimálním složení a vedení přináší týmové učení synergický efekt - dovednosti, znalosti a schopnosti jeho členů se navzájem doplňují a tím pomáhají rychlému řešení stávajícího problému; pozitivem je především kreativní myšlení, schopnost nacházet řešení problému, přijímat příslušná rozhodnutí, vzájemná spolupráce. Některé týmy se integrují tak silně, že zpětně je téměř vyloučeno poznat, kdo byl iniciátorem prvotního nápadu vedoucího následně k řešení problému. Takové týmy jsou základní stavební jednotkou učíci se organizace, součástí jejich učení je dialog, tzn. schopnost kreativně rozvíjet myšlenky a nápady, umět obhájit vlastní stanovisko v procesu utváření společného řešení. Při optimálním vedení týmů navíc dochází ke zlepšení komunikace a toků informací v organizaci, k lepšímu využití zdrojů, ke zlepšení tvưrčí činnosti při řešení problémů, ke zvýšení výkonnosti a účinnosti celé organizace, poněvadž tým má možnost dosáhnout mnohem více než běžná skupina lidí.

Koordinované úsilí všech členů týmu má synergický efekt, je vyšší než pomysIný součet individuálních snah. Členové týmu se spoléhají jeden na druhého a slabost jednotlivce se kompenzuje silnými stránkami ostatních. Tím, že se doplňují jejich silné stránky a vytváři se ovzduší důvěry mezi členy týmu, jejich koordinovaná činnost vytváří kvalitativně lepší výsledky, průhledný proces řešení problémů, vyšší motivaci a efektivnější rozhodování.

Takové týmy však nevznikají ani nefungují samy od sebe, ale musí být nejprve sestaveny a následně vedeny tak, aby vznikla atmosféra otevřenosti přiznat neznalost, umět požádat o pomoc při zjištování něčeho nového a důvěra i při procesu učení - řešení problémů. Jedná se o klíčové vlastnosti nezbytné $k$ tomu, aby byly veškeré rozpory řešeny neprodleně, členové týmu se učili jeden od druhého, pracovali samostatně nebo v podskupinách, ale vždy měli na zřeteli hlavní cíl a jeho splnění - proměnu školy, zlepšení výchovně vzdělávacího procesu, klimatu, kultury školy atd.

Aby tato atmosféra mohla být navozena, musí vedoucí týmu zastávat vůdčí úlohu - iniciovat pravidelné kontroly plnění úkolů jednotlivých členů týmu nebo celého kolektivu a zajištovat konstruktivní zpětnou vazbu, tzn., že ředitel školy musí při vytváření týmů postupovat systematicky v několika krocích:

- Najít učitele, kteří se do jednotlivých týmů budou hodit po stránce odborné, sociální, komunikační atd.. , musí u nich vytvořit pocit vzájemné odpovědnosti za daný úkol.

- Vymezit, proč byl tým vytvořen, za jakým účelem; všichni členové týmu musí umět odpovědět na otázku - Proč tým funguje, jaké je moje místo v týmu, jaké jsou mé pravomoci, role v týmu, jaké jsou hodnoty týmu, co mě motivuje k dosažení cíle.

- Stanovit trasu a „jízdní rád týmu“ - jakým způsobem bude dosaženo vytčených cílı̊, jakými konkrétními kroky, v jakých termínech, kdo a jak bude kontrolovat postup práce týmu.

- Vytvořit atmosféru, kde jsou lidé vedeni k samostatnému uvažování, ke sdí- 
lení informací, k hledání nových znalostí.

- Vytvořit prostředí hledání a učení se $z$ uskutečněného u učitelů i žáků - Co jsme měli splnit, jaký byl náš cíl? Co se ve skutečnosti stalo, čeho jsme dosáhli? Proč vznikly rozdíly? Jak se $z$ toho můžeme poučit? Které úspěšné kroky vedly $k$ dosažení našeho cíle? Jaké metody, formy práce se osvědčily? Jsou využitelné pro výuku, pro další aktivity školy? Jak výsledky zveřejníme?

- Deklarovat, že v procesu vytváření učící se organizace se všichni účastníci procesu, učitelé i žáci, jednotlivci i týmy mohou dopustit chyby, poněvadž i ty jsou součástí učení a mohou být využity pro rozvoj organizace i jejích členů. Některé z největších objevů lidstva jsou důsledkem chyb. Zdravá míra chybování je zdrojem úspěchu, protože je dokladem vyhledávání a vytváření nových př́ležitostí. Ti, kteří dělají chyby, se učí nést za ně odpovědnost a neopakovat je.

- Podporovat co největší výměnu znalostí a dovedností mezi týmy i jednotlivci - kdekoli se sejdou alespoň dva lidé, mají přiležitost si vyměňovat informace a tak se učit - u učitelů toto pravidlo je téměř konstantou a „profesním zatížením". Vytvářet učící se atmosféru ve škole by pro vedoucího pracovníka nemuselo být proto těžké, může $\mathrm{k}$ tomu docházet téměř konstantně.

Týmové řízení je pro vedoucí pracovníky jedním z nejnáročnějších, poněvadž vyžaduje vysokou úroveň kompetencí vůdce v oblasti motivování a přesvědčování - týmy se liší od běžných skupin lidí. Skupiny se navzájem střetávají a ovlivňují, týmy sice mohou vykazovat podobné znaky, ale kromě toho se vyznačují silnou vzájemnou jednolitou identitou, mají společné cíle nebo úkoly a jejich členové navzájem na sebe spoléhají, cítí zodpovědnost jeden za druhého, protože se učí jeden od druhého. Ta však nevzniká sama od sebe, ale musí být minimálně iniciována, ne-li stále podporována, motivována a rozvíjena. Navíc charakteristickou vlastností všech vysoce efektivních týmů je zodpovědnost vedoucího týmu (tj. ředitele školy) za osobní růst a úspěch každého člena týmu. Jde tedy nejen o dosahování úkolů prostřednictvím jiných lidí, ale o vytváření prostoru pro seberealizaci podř́zených.

\section{Závěr}

V současné době lze vývoj školství charakterizovat dvěma kategoriemi - změny $v$ návaznosti na reformy vzdělávacích systémů. Významným znakem reforem vzdělávacích systémů je, že těžiště změn je směřováno na školy samotné. Díky školním vzdělávacím programům, vlastnímu hodnocení školy, konkurenci mezi školami sílí tendence zohledňovat specifika a rozdíly mezi jednotlivými školami, je kladen důraz na stanovování požadavků, potřeb a hodnot ve vztahu k možnostem školy, jsou podporovány interakční vazby a týmová spolupráce. $S$ tím souvisí jak změny ve struktuře vzdělávacích systémů - řízení, správě, financování, tak především v jednotlivých prvcích - v pojetí školního vzdělávání, v prístupu k žákům, v nárocích na metody a formy výuky; díky informačním technologiím je kladen důraz na nové 
formy a způsoby komunikace umožňující novou kulturu učení. Mění se jak vztah mezi žákem a učitelem, tak mezi učitelem a vedením školy.

Řízení školy jako učíí se organizace vyžaduje kompetence leadera, které se promítají především v profesionálním řízení změn a vedení týmů, vyžaduje profesionála, který motivuje pracovníky být kompetentními mistry ve svých odbornostech a specializacích, sdílet tyto zkušenosti, vnímat problémy v souvislostech a v proměnách požadavků doby. Náročnost vnějšího prostředí, které dnešní školu obklopuje, vyžaduje, aby ředitel byl současně i manažerem a vykonavatelem, což je propojenost nejednoduchá, ale jak školská praxe ukazuje, u řady ředitelů škol na vysoké profesní úrovni zvládnutelná.

Kompetenční pravidlo říká, že úspěchy a neúspěchy firem souvisejí s kompetencemi lidí, kteří pro firmu pracují. Silnou stránkou řídících pracovníků v učících se organizacích by tedy mělo být vytváření takových kompetencí u jeho podřizených, které je budou motivovat k poznávání, k objevování a sdílení nalezeného. Jinými slovy motivovat je k tomu být vynikajícími učiteli, od nichž se ostatní učí, poněvadž velcí učitelé vytvářejí prostor pro ostatní a zvou do tohoto prostoru lidi - žáky, kolegy, .... Není to úkol jednoduchý, nebot vůdčí osobnosti, jako jednotlivci i kolektivně, usilují o změnu rádu věcí....a "být leaderem je jako být prorokem, protože ve školách nepřipravujeme žáky a studenty pro svět, v němž jsme až dosud žili, ale pro budoucnost, kterou si sotva dokážeme představit." G. Brown.

\section{Literatura}

Bolcek, L. Diagnostika učící se organizace. Praha, 2005. 57 s. Česká zemědělská univerzita v Praze. Provozně ekonomická fakulta. Literární rešerše k disertační práci.

Drucker, P. F. To nejdůležitější z Druckera v jednom svazku. Praha: Management Press, 2002. ISBN 80-7261-066-X.

Kiechel, W. The organizations that learns. Fortune, 1990, Vol. 121, March 12, s. 75-77. ISSN 0012-8259.

Kotásek, J. Budoucnost školy a vzdělávání. In Walterová, E., aj. Úloha školy v rozvoji vzdělanosti. 2. díl. Brno: Paido, 2004, s. 441-484. ISBN 80-7315-083-2.

Kotter, J. Vedení procesu změny. Praha: Management Press, 2000. ISBN 80-7261-015-5.

Lisabonská smlouva pozměňující smlouvu o Evropské unii a smlouvu o založení Evropské unie [online]. Brusel, 2007. Dostupné na WWW: < http://www. euroskop.cz/192/sekce/ke-stazeni>.

Pol, M. Škola $v$ proměnách. Brno: Masarykova univerzita, 2007. ISBN 978-80-210-4499-9.

Senge, P. M. Pátá disciplína. Teorie a praxe učící se organizace. Praha: Management Press, 2007. ISBN 978-80-7261-162-1.

Slavíková, L. Řizení pedagogického procesu. Praha: CŠM PedF UK, 2007.

Slavíková, L. Výzkumná zpráva k projektu Úspěšný ředitel. Praha: CŠM PedF UK, 
2008.

Schartz, M. Leader or manager. Vilnius, 2007. Prezentace na konferenci Challenges in schools. Rovněž POL, M. Škola v proměnách. Brno: Masarykova univerzita, 2007, s. 33. ISBN 978-80-210-4499-9.

Strategie celoživotního učení ČR. Praha : MSMT 2008, TAURIS.

ISBN 978-80-254-2218-2

Tichá, I. Učící se organizace. Praha: Česká zemědělská univerzita, Provozně ekonomická fakulta,1999. ISBN 80-213-0574-6.

Tichá, I. Učící se organizace. Praha. Univerzita Karlova v Praze. Pedagogická fakulta. Centrum školského managementu. Studijní text pro účastníky kurzu distančního vzdělávání rídících pracovníků, 2008.

Vaštatková, J.; Prášilová, M. Česká škola = učící se škola? Pedagogická orientace, 2007, č. 1, s. 5-11. ISSN 1211-4669. 